\title{
Quantitative Evaluation of Reciprocal Herkogamy in the Distylous Species, Hedyotis caerulea (Rubiaceae)
}

Dennis A. Sampson

Cleveland State University, dennys1988@yahoo.com

Robert A. Krebs

Cleveland State University, r.krebs@csuohio.edu

Follow this and additional works at: https://engagedscholarship.csuohio.edu/scibges_facpub

Part of the Biology Commons

How does access to this work benefit you? Let us know!

Publisher's Statement

The final publication is available at Springer via http://dx.doi.org/10.1007/s00606-012-0642-4

\section{Recommended Citation}

Sampson D and Krebs R. 2012. Quantitative evaluation of reciprocal herkogamy in the distylous species, hedyotis caerulea (rubiaceae). Plant Syst Evol 298(7):1361-70.

This Article is brought to you for free and open access by the Biological, Geological, and Environmental Sciences Department at EngagedScholarship@CSU. It has been accepted for inclusion in Biological, Geological, and Environmental Faculty Publications by an authorized administrator of EngagedScholarship@CSU. For more information, please contact library.es@csuohio.edu. 


\title{
Quantitative evaluation of reciprocal herkogamy in the distylous species, Hedyotis caerulea (Rubiaceae)
}

\author{
Dennis A. Sampson • Robert A. Krebs
}

\begin{abstract}
Hedyotis caerulea possesses two distinct floral morphs that are generally found in equal numbers in naturally occurring populations. Flowers either possess a relatively long style and short anthers, called a "pin," or a short style and long anthers, called a "thrum." This placement of reproductive organs is considered herkogamous and distylous, as it encourages outcrossing by restricting pollination to individuals of the alternate morph. Numerous species have been described as distylous without quantitative data establishing stigma-anther reciprocity. Here we assess those assumptions in $H$. caerulea by measuring stigma height, anther height and a suite of additional floral traits across multiple localities. All populations surveyed were isoplethic, although variation among them was present in all floral traits measured as well as for pollen diameter, pollen count, flower dry weight, and seed set. Pins produced smaller pollen than thrums, but made more of them. Thus, the total volume of pollen was similar for pins and thrums, and seed set was similar, suggesting that each morph has equal male and female fitness with no movement towards dioecy. Given a significant degree of variation found in the morphometric analysis, and that two of the three measures used to assess reciprocity were not consistent with predictions of precise symmetry, extensive change is possible where selection is acting on these traits. Even so, the distylous mating system in $H$. caerulea appears to be stable.
\end{abstract}

\footnotetext{
D. A. Sampson · R. A. Krebs ( $\square)$

Department of Biological, Geological, and Environmental

Sciences, Cleveland State University, 2121 Euclid Ave.,

Cleveland, OH 44115-2406, USA

e-mail: r.krebs@csuohio.edu

D. A. Sampson

e-mail: dennys1988@yahoo.com
}

Keywords Bluets · Distyly · Flowers · Houstonia . Isoplethy $\cdot$ Floral morphology

\section{Introduction}

Variation in morph frequency in distylous plants can provide information on the dynamics of selection on genes controlling flower morphology and mating systems (Barrett and Eckert 1990), topics that have renewed a focus on distylous systems (Weller 2009; Cohen 2010). Since distyly promotes outcrossing through intermorph pollen transfer (disassortative mating), this reproductive strategy is expected to produce populations with an equilibrium state of 1:1 (isoplethy), ready availability of compatible pollen, and equivalent reproductive success (Barrett 1992; Matsumura and Washitani 2000; Kéry et al. 2003; Shibayama and Kadono 2003). Heuch (1979) has shown theoretically that, provided no fitness differences among the style morphs exist, an isoplethic equilibrium is the only possible condition in large populations with disassortative mating (i.e., in distylous plant species). A fully distylous species would be made of individuals with equal male and female fitness, and would be typified by equivalent amounts of pollen from each morph fertilizing the stigmas of the opposite morph (Sutherland and Delph 1984).

A related expectation in distylous species is that the height of the pin stigmas within the flower will match that of the thrum anthers, and height of the pin anthers matches that of the thrum stigmas (Webb and Lloyd 1986; Lloyd and Webb 1992a), potentially to achieve better pollen placement. Called reciprocal herkogamy (Darwin 1877), this condition has traditionally been necessary and sufficient to characterize a flowering species as distylous (Richards 1986; Webb and Lloyd 1986; Chen and Zhang 
2010). Darwin (1877) proposed that reciprocal herkogamy is adaptive within his "Disassortative Pollen Flow" hypothesis. He predicted that pollen from the two morphs would be carried on different locations on pollinators' bodies. Thus, pollen from a pin flower would be positioned to be transferred to the stigma of a thrum flower, and vice versa, resulting in a greater proportion of legitimate pollen flow (pollen transfer in which the recipient and donor flowers are different morphs) than illegitimate pollen flow (in which the recipient and donor flowers are the same morph) compared to that expected from random placement of pollen. The resulting outcrossing advantage is thought to have driven the evolution and maintenance of distyly (Darwin 1877; Lloyd and Webb 1992a).

In addition to length variation, the receptive surface of the pin morph is typically larger than that of the thrum (e.g., in Jepsonia parryi: Ornduff 1970). In contrast, thrum stigmas are larger than pin stigmas in Amsinckia grandiflora (Ornduff 1976) and Primula malacoides (Pandey and Troughton 1974). In Rudgea jasminoides, thrum stigmas are long, narrow, and curled, whereas pin stigmas are short and flat (Baker 1956). The most frequently reported polymorphism of stigmas is that papillae in pins are larger than those in thrums (Vuilleumier 1967; Dulberger 1974). However, actual measurements of papilla size are documented in relatively few plants (e.g., Lythrum junceum: Dulberger 1970; L. curtisii: Ornduff 1978; Pulmonaria obscura: Oleson 1979).

Like many putatively distylous species, the functional components of Hedyotis caerulea have been little studied. Ornduff $(1977,1980)$ measured pollen flow and seed set in 19 localities in North Carolina over a period of several successive years and found that although compatible pollen flow from pins to thrums was greater than from thrums to pins, seed production by the two morphs was similar. Wyatt and Hellwig (1979) studied six localities in North Carolina and also observed that pins and thrums produce the same number of buds, flowers, and capsules per plant, while Grimaldi (1988) reported that pins slightly outnumbered thrums in several New York localities, and he suggested that pin and thrum ratios may vary at certain times of the flowering period.

In order to evaluate the functional status of distyly in naturally occurring populations of $H$. caerulea in northeastern Ohio, this study focused on morph ratios, a calculated self-compatibility index, and the functional gender of the two morphs. To verify distyly, we also performed a proper assessment of reciprocity as put forth by Faivre and McDade (2001) and by Richards and Koptur (1993). While the nature of distyly may be complex, Mather and de Winton (1941) and Dulberger (1975) have suggested that an association among floral traits may function in an integrated fashion and may have evolved together to promote cross-fertilization (Darwin 1877; Lloyd and Webb 1992b). Thus, quantitative analyses of the ancillary traits in heterostylous species are included to shed light on the functional significance of floral variation and the evolution of heterostyly.

\section{Materials and methods}

Morph frequencies

Initially 12 localities of $H$. caerulea in or near the Cleveland Metroparks were surveyed for morph ratio in May of 2005 (Fig. 1, \#1-12). Subsequently, four sites were surveyed every 2 weeks over the 2008 growing season (i.e., on May 7, May 18, June 1, and June 14): nos. 1, 7A, and $7 \mathrm{~B}$ (two replicates produced by subdividing the large population no. 7 as north and south), and no. 13. In each survey the number of individual pins and thrums, the number of flowers per individual pin and thrum, and the number of capsules per individual pin and thrum were counted. Because of the the difficulty in finding and identifying the morph of a plant without at least one flower, only flowering individuals were counted.

\section{Morphometric analysis}

One flower from each plant was collected from localities 1-10. Collections were separated and identified to morph after which 40 pin flowers and 40 thrum flowers were selected by drawing them blindly from a pool of flowers of each morph in a petri dish. The only exception was site 3, where a relatively small size of the population limited collection to only 20 pin individuals, although 40 thrum individuals were sampled. All flowers were preserved in $3 \%$ formalin for measurement of anther height, stigma height, and the difference between stigma height and anther height.

Anther height $(\mathrm{AH})$ was measured from just above the inferior ovary to the tip of the longest anther (Fig. 2); stigma height ( $\mathrm{SH}$ ) was measured from just above the inferior ovary to the tip of the longer bifurcation of the stigma; difference between anther height and stigma height (D) was calculated as the absolute value of the difference AH-SH. Stigma length (SL), width of corolla tube base (CB), and width of corolla tube top (CT) were measured on these same flowers. Measurements were made using an Olympus SZX12 dissecting microscope equipped with an ocular micrometer accurate to $<0.01 \mathrm{~mm}$ at $90 \mathrm{X}$, its highest resolution.

In May 2007, papilla length was measured in independent sampling at five of these localities (nos. 1, 2, 7, 9, and 10). Flowers were collected from each site and preserved in 
Fig. 1 Location of sites from which Hedyotis caerulea were sampled. Shaded areas represent natural areas within the Cleveland Metroparks system in Cuyahoga County, Ohio, which was established in 1917. Urbanization dominates much of the surrounding lands

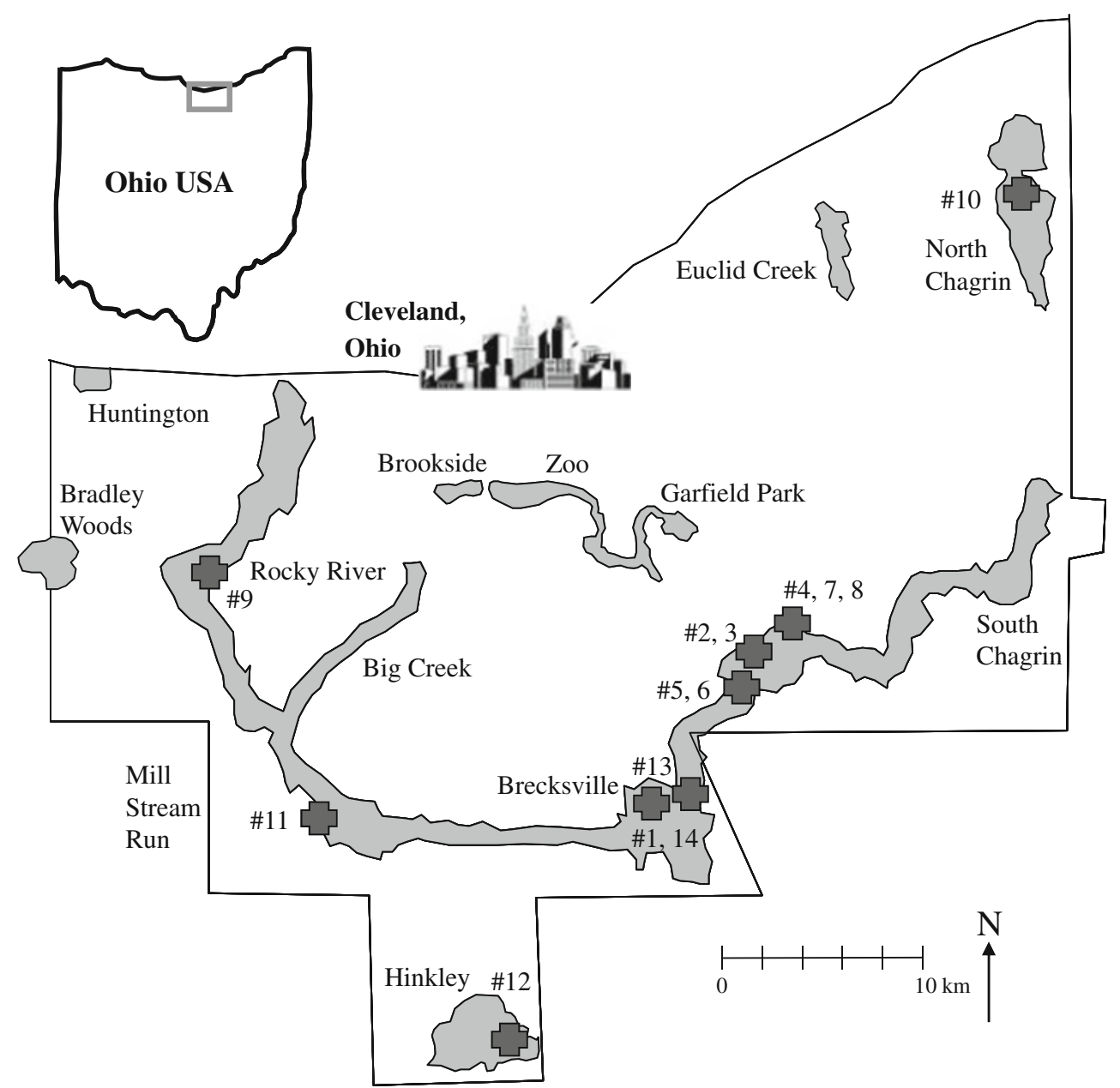

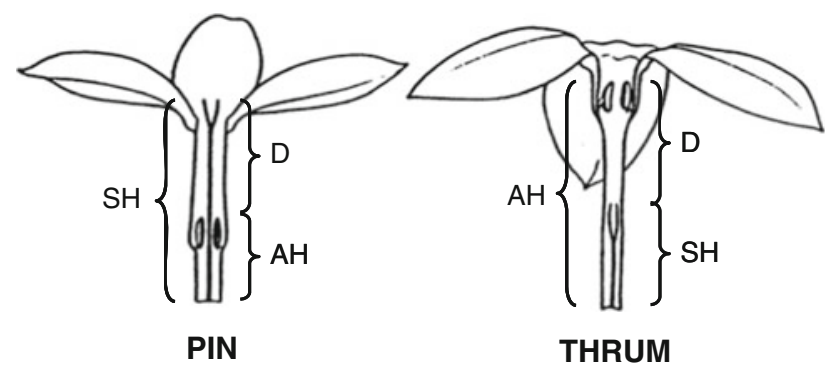

Fig. 2 The measurement of SH stigma height, AH anther height, and $\mathrm{D}$ the absolute value of the difference between the anther height and the stigma height

$70 \%$ ethanol. The length of four papillae on each stigma was measured for 15 pin flowers and 15 thrum flowers using an ocular micrometer in a Leitz Dialux EB20 compound microscope. The most clearly visible papilla in the best-focused field of view was measured on each side of the stigma's bifurcation. Pollen was similarly sampled in six localities (nos. 1, 2, 6, 7, 9, and 10), 15 pin and thrum flowers per locality and 3 pollen grains per flower. Pollen was suspended in water with two drops of methylene blue, and one drop of detergent, and measured with the Leitz Dialux EB20 microscope.

Reproductive output

Pollen count per anther sac was estimated in samples from four localities in 2008 (localities 2, 9, 10, and 14). Ten pin flowers and ten thrum flowers were collected from each site. One of the four anthers from each flower was placed in a small plastic vial with $70 \%$ ethanol, two drops of methylene blue, and one drop of detergent, for a total volume of $1 \mathrm{ml}$. The pollen was suspended throughout the liquid in the vial using a vortex mixer. The pollen grains contained within $0.1 \mathrm{ml}$ of the suspension were scored using the Leitz Dialux EB20 microscope and a slide equipped with a grid. Total pollen count was calculated for each anther sac.

Concurrent with pollen sampling, flower dry weights were estimated using newly opened pin and thrum flowers to minimize the contribution of inferior ovaries, 25 per morph from each of three localities (nos. 2, 10 and 14). The flowers were placed in individual weighing vials and 
heated in a drying oven for 3 days. The vials were weighed using a microbalance (Mettler AB54) first with the dried flower inside and then empty; dry flower weight was calculated by subtraction. Subsequently, mature capsules ( $N=4$ per population and morph) were also collected at these localities. Each capsule was opened using a dissecting needle, and the seeds were counted under a dissecting microscope (SZ30).

\section{Statistical analyses}

For each population study, variation among individuals of the same floral morph was assessed by mixed-model ANOVA [morph type was a fixed effect, locality was a variable effect, and where used, replicate measurements of individuals were nested within locality (SAS, 1990)]. Assessment of reciprocity was made using three different methods: (1) by comparison of the absolute value of anther height less stigma height (as in Faivre and McDade 2001); (2) by measuring the relative reciprocity between organ levels (as in Richards and Koptur 1993) calculated for each organ level as (Anther Height-Reciprocal Stigma Height)/(Anther Height + Reciprocal Stigma Height).

\section{Results}

All populations were isoplethic. The morph ratio of pins to thrums was not different from 1:1 (individual $\chi^{2}$ tests), with the possible exception of population 3 (Table 1). No difference was significant on an experiment-wise level, and an independent follow-up survey of population 3 in 2008 confirmed a morph ratio of 1:1 (results in Sampson 2010).

Distyly was indicated by the distributions of stigma and anther heights, which were bimodal and without overlap between the two morphs (Fig. 3). Across ten localities, the mean pin stigma height was $5.95 \pm 0.10 \mathrm{~mm}(\mathrm{CV}=0.33)$, and the mean thrum stigma height was $3.79 \pm 0.07 \mathrm{~mm}$ $(\mathrm{CV}=0.33)$, a significant difference between morphs (Fig. 4a, $F_{1,9}=1,310, P<0.0001$ ). Conversely, anther height across these localities was for pins, $3.16 \pm 0.03$ $(\mathrm{CV}=0.29)$, and for thrums, $6.62 \pm 0.10(\mathrm{CV}=0.33)$, which was also significant (Fig. 4b, $F_{1,9}=1,836$, $P<0.0001)$. Between-morph variation in the species accounted for $73 \%$ of the total variation in stigmas and $90 \%$ of the total variation for anthers. The difference in the height of the stigma and that of the anther was similar and not significantly variable among localities (Fig. 4c), although a significant locality effect was shown in both morphs $\left(F_{9,760}=8.61, P<0.0001\right)$, as well as an interaction between locality and morph $\left(F_{9,760}=7.68\right.$, $P<0.0001)$. These differences related more to size variation among flowers from these localities. Separating analysis of variation for stigma height of pins $\left(F_{9,390}=8.29\right.$, $P<0.0001)$ and thrums $\left(F_{9,370}=5.53, \quad P<0.0001\right)$ showed both were significant, but locality variation in anther height was significant only in thrums $\left(F_{9,370}=6.47\right.$, $P<0.0001)$, but not pins $\left(F_{9,390}=2.43\right.$, NS), possibly because pin anthers lie so close to the flower base.

Given a pronounced dimorphism, reciprocity of organ placement was assessed three ways. First, mean heights of the two long organs and the two short organs were predicted to be similar. Mean height of thrum anthers

Table 1 Flower number and morph ratio of pins to thrums observed in a survey of 12 populations of Hedyotis caerulea in the greater Cleveland area

\begin{tabular}{|c|c|c|c|c|c|c|}
\hline Site no. & Location & $N$ & No. pins & No. thrums & $\chi^{2}$ & Morph ratio \\
\hline 1 & Brecksville Reservation $41.305^{\circ} \mathrm{N}, 81.609^{\circ} \mathrm{W}$ & 326 & 169 & 157 & 0.22 & $1: 1$ \\
\hline 2 & Bedford Reservation $41.383^{\circ} \mathrm{N}, 81.568^{\circ} \mathrm{W}$ & 338 & 156 & 182 & 1 & $1: 1$ \\
\hline 3 & Bedford Reservation $41.386^{\circ} \mathrm{N}, 81.552^{\circ} \mathrm{W}$ & 68 & 49 & 19 & $4.97 *$ & $2.6: 1$ \\
\hline 4 & Bedford Reservation $41.386^{\circ} \mathrm{N}, 81.539^{\circ} \mathrm{W}$ & 543 & 275 & 268 & 0.045 & $1: 1$ \\
\hline 5 & Bedford Reservation $41.377^{\circ} \mathrm{N}, 81.574^{\circ} \mathrm{W}$ & 883 & 443 & 440 & 0.046 & $1: 1$ \\
\hline 6 & Bedford Reservation $41.375^{\circ} \mathrm{N}, 81.571^{\circ} \mathrm{W}$ & 254 & 122 & 132 & 0.20 & $1: 1$ \\
\hline 7 & Bedford Reservation $41.385^{\circ} \mathrm{N}, 81.536^{\circ} \mathrm{W}$ & 89 & 42 & 47 & 0.14 & $1: 1$ \\
\hline 8 & Bedford Reservation $41.385^{\circ} \mathrm{N}, 81.537^{\circ} \mathrm{W}$ & 200 & 105 & 95 & 0.25 & $1: 1$ \\
\hline 9 & Rocky River Reservation $41.408^{\circ} \mathrm{N}, 81.883^{\circ} \mathrm{W}$ & 825 & 407 & 418 & 0.073 & $1: 1$ \\
\hline 10 & North Chagrin Reservation $41.580^{\circ} \mathrm{N}, 81.431^{\circ} \mathrm{W}$ & 913 & 466 & 447 & 0.22 & $1: 1$ \\
\hline 11 & Strongsville $41.297^{\circ} \mathrm{N}, 81.811^{\circ} \mathrm{W}$ & 266 & 127 & 139 & 0.27 & $1: 1$ \\
\hline 12 & State Road, Hinckley $41.205^{\circ} \mathrm{N}, 81.711^{\circ} \mathrm{W}$ & 147 & 81 & 66 & 0.76 & $1: 1$ \\
\hline
\end{tabular}

Populations along trails $(1,3,4,5,6,8,12)$ were exposed to nearly full sunlight part of the day and diffuse sun part of the day, while populations located either on the edges of picnic areas $(7,9,10)$ or in an open field (2) or lawn (11) received full sunlight all day

$* P<0.05$, but not significant at an experiment-wise level 


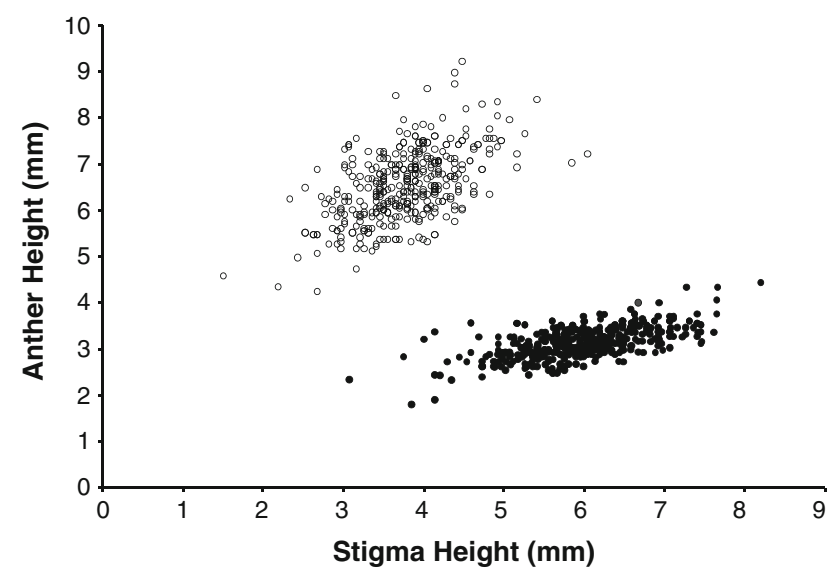

Fig. 3 Scatterplot representing the anther and stigma heights (in $\mathrm{mm}$ ) of individual flowers; filled circles are pins $(N=400)$, open circles are thrums $(N=380)$
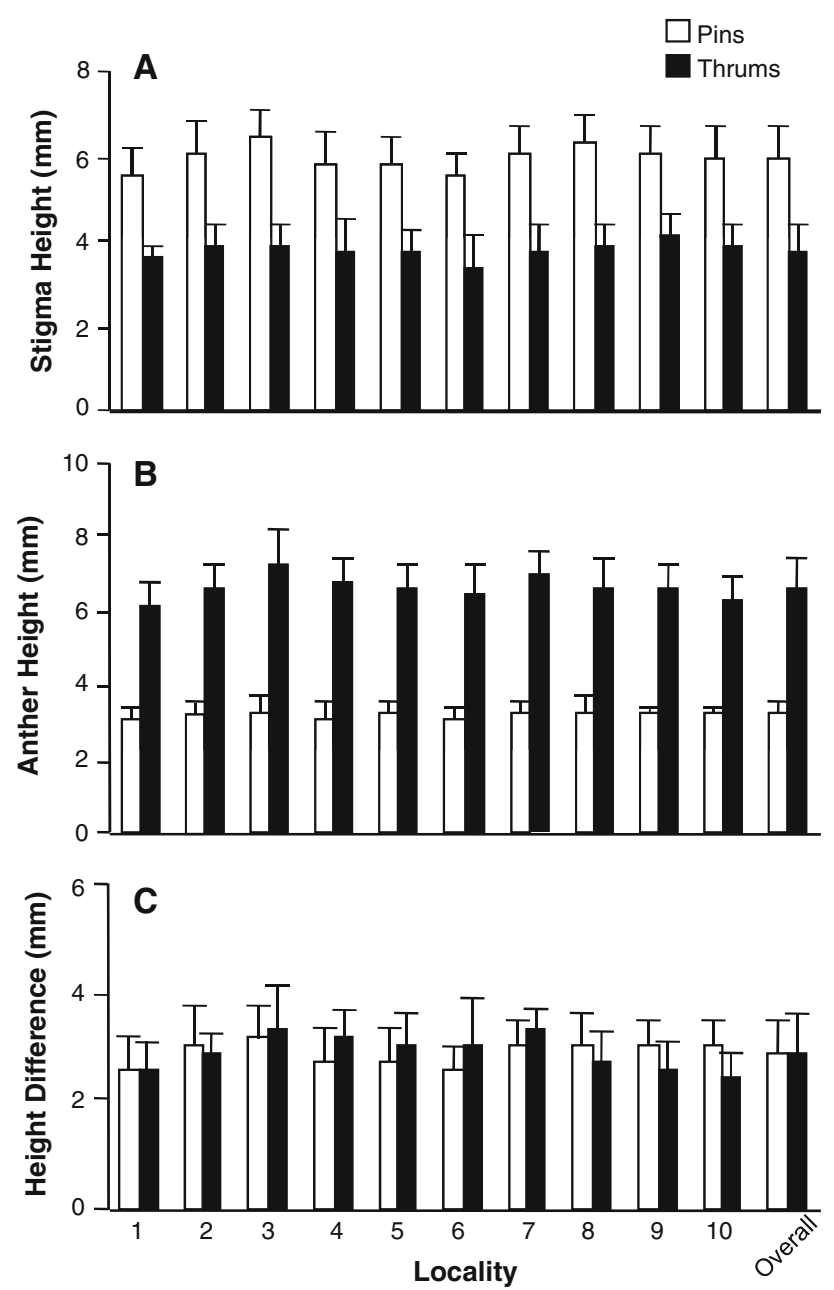

Fig. 4 The measurement of herkogamy in ten populations of Hedyotis caerulea (bars represent one standard error): a mean stigma height, $\mathbf{b}$ mean anther height, and $\mathbf{c}$ mean absolute value of difference between anther height and stigma height
(6.62 mm) significantly $(P<0.0001)$ exceeded that of pin stigmas $(5.95 \mathrm{~mm})$. Similarly, thrum stigmas $(3.79 \mathrm{~mm})$ were significantly $(P<0.0001)$ longer than pin anthers $(3.11 \mathrm{~mm})$. Second, the mean difference between stigma and anther heights was compared between morphs (see Fig. 4c) and found to be similar $(F=0.53$, NS). Third, relative reciprocity indices were calculated for the short organs at 0.053 and for the long organs at -0.091 .

\section{Ancillary characteristics}

In addition to the separation in the position of the anthers and stigmas, the morphology of the corolla tube varied between the two morphs (Fig. 2). In thrums, the width of the corolla tube was greater at the mouth $(1.80 \pm 0.01 \mathrm{~mm}$, $\mathrm{CV}=0.11)$ than it was in pins $(1.47 \pm 0.01 \mathrm{~mm}$, $\mathrm{CV}=0.12)\left(F_{1,9}=598, P<0.0001\right)$ to make room for the anthers (Fig. 5a). Pins correspondingly possessed a wider corolla tube at the base $(1.14 \pm 0.01 \mathrm{~mm}, \mathrm{CV}=0.15)$, where their anthers are located (Fig. 5b), than do thrums $\left(0.80 \pm 0.01 \mathrm{~mm}, \mathrm{CV}=0.15 ; F_{1,9}=1277, P<0.0001\right)$. A significant locality effect occurred for width of the tube top $\left(F_{1,9}=7.07, P<0.0001\right)$ in both pins $\left(F_{9,390}=5.98\right.$, $P<0.0001)$ and thrums $\left(F_{9,370}=3.46, P<0.001\right)$, but without a significant interaction between morph and locality $\left(F_{1,9}=2.22, \mathrm{NS}\right)$. Similarly, variation among localities was significant for the tube base $\left(F_{9,760}=14.12, P<0.0001\right)$, which was present in both pins $\left(F_{9,390}=16.72, P<0.0001\right)$ and thrums $\left(F_{9,370}=2.77, P<0.001\right)$. An interaction between morph and locality was also significant $\left(F_{9,760}=6.17, P<0.0001\right)$.

Unlike the corolla tubes, lengths of the stigmas above the bifurcation (Fig 1) did not appear to differ appreciably $\left(F_{1,9}=0.53\right.$, NS $)$ between pins and thrums. Across ten localities, stigma length was $1.36 \pm 0.02 \mathrm{~mm}(\mathrm{CV}=0.24)$ in pins and $1.37 \pm 0.02 \mathrm{~mm}(\mathrm{CV}=0.22)$ in thrums (Fig. 5c). A locality effect $\left(F_{9,760}=8.61, P<0.0001\right)$ and an interaction between morph and locality $\left(F_{9,760}=7.86\right.$, $P<0.0001$ ) were significant.

A correlation analysis of the variation in stigma height, anther height, the difference among stigma height and anther height, stigma length, corolla tube width at the top, and corolla tube width at the base showed a number of relationships among traits and a pattern that differed between pins and thrums (Table 2). Variation in both pin and thrum flowers produced strong correlations between the corolla tube width at the top and at the base (reflecting the shape of the pin corolla tube). Features of the long organs, stigma height in pins and anther height in thrums, showed stronger correlations than features of the short organs. In pins, corolla tube width at the top correlated strongly with stigma height, stigma length, and the difference between stigma height and anther height. Stigma 

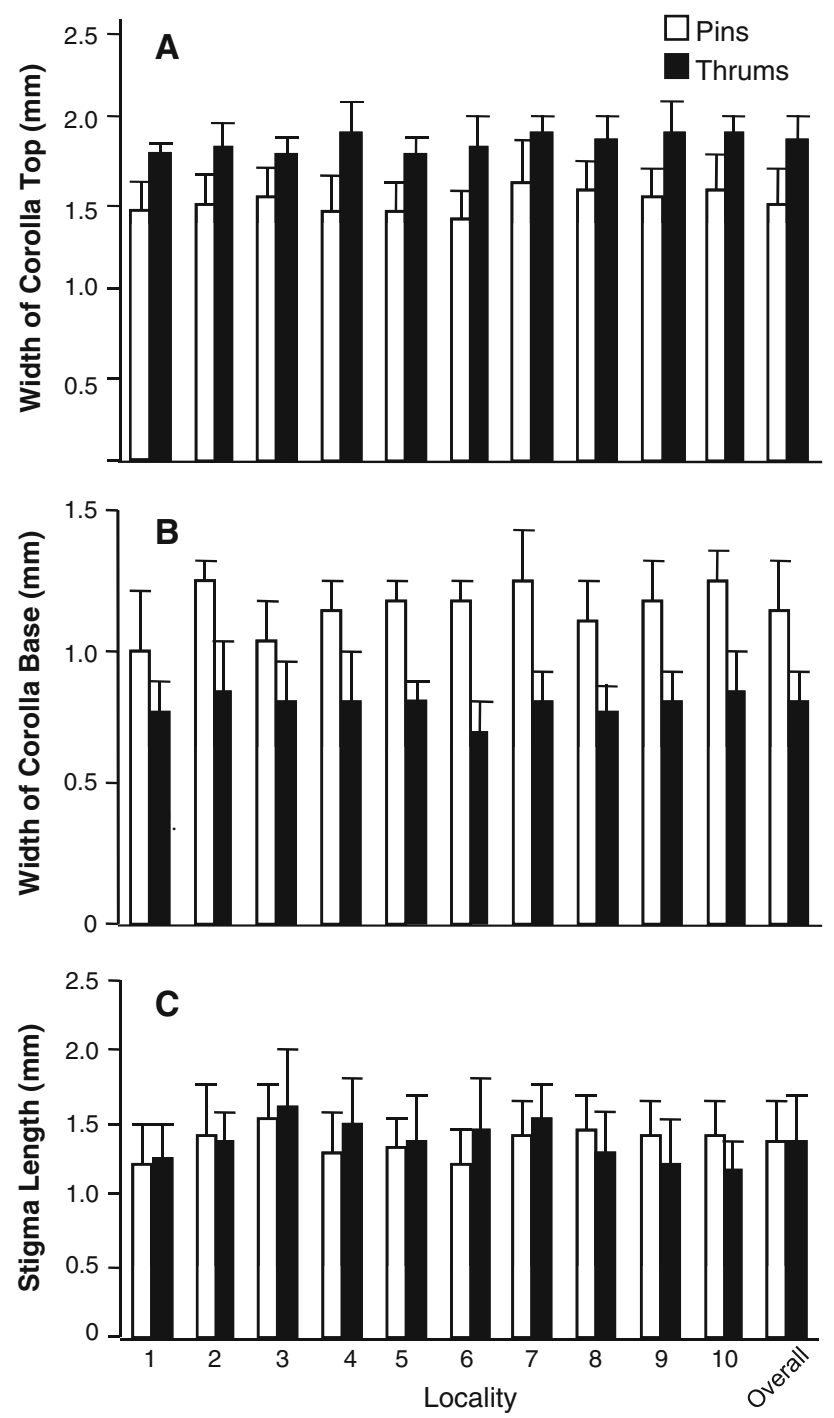

Fig. 5 The measurement of several ancillary characters in ten populations of Hedyotis caerulea (bars represent one standard error): a mean width of corolla tubes (at top), $\mathbf{b}$ mean width of corolla tube (at base), and c. mean stigma length

length also correlated strongly with stigma height and distance between stigma height and anther height $(P<0.0001$ for each). In thrum flowers, anther height correlated strongly with stigma length, stigma height, corolla tube width at the top, and the difference between stigma height and anther height $(P<0.0001)$. Stigma height and stigma length correlated strongly $(P<0.0001)$.

Fitness characters

Contributing to variation in morphology, pin and thrum morphs varied in flower size. The mean dry weight for a pin flower was $1.183 \pm 0.059 \mathrm{mg}$, and for a thrum flower $1.443 \pm 0.071 \mathrm{mg}$. While the difference in dry weight between morphs was significant $\left(F_{1,144}=6.79, P<0.01\right)$, locality effects accounted for a greater amount of the variation among weights of flowers across the three localities sampled $\left(F_{2,144}=16.0, P<0.0001\right)$. The interaction effect between morph and locality was not significant.

As is common in distylous species, pollen grain size differed significantly $\left(F_{1,5}=98.3, P<0.0001\right)$ between morphs, as the diameter of pin pollen was smaller at $24.8 \pm 0.16 \mu \mathrm{m}(\mathrm{CV}=0.16)$ than that of thrum pollen at $29.7 \pm 0.20 \mu \mathrm{m}(\mathrm{CV}=0.12)$ (Fig. 6a). Pollen size varied spatially as a locality effect, and was present in both pins $\left(F_{5,270}=3.20, P=0.015\right)$ and in thrums $\left(F_{5,270}=14.9\right.$, $P<0.0001)$, and for both morphs, individuals within locality also varied in pollen size $\left[F_{24,270}=5.28\right.$ in pins $(P<0.0001)$ and $F_{24,270}=8.57$ in thrums $\left.(P<0.0001)\right]$.

Pollen grain quantity likewise differed between morphs, but inversely to pollen size. Pins produced significantly more pollen grains than did thrums based on samples from four localities, with $856 \pm 67.4$ pollen grains per anther sac in pins compared to $583 \pm 49.8$ per anther sac in thrum flowers $(P<0.001)$. Mean pollen counts per locality also varied $(P=0.012)$, and ranged from $752 \pm 181$ to $937 \pm 93.7$ in pins and from $483 \pm 55.2$ to $672 \pm 130$ in thrums (Fig. 6b). Therefore, on average pins produced a pollen volume of about $0.055 \mathrm{~mm}^{3}$ and thrums $0.064 \mathrm{~mm}^{3}$.

In contrast, differences between morphs in seed number produced per capsule (Fig. 6c) were small (11.0 \pm 0.58 seeds per pin capsules and $11.5 \pm 0.54$ seeds per thrum capsule, $P=0.67, \mathrm{NS})$, although a significant locality effect occurred $(P<0.05)$. However, related to pollen size, the length of stigma papillae differed significantly between morphs $\left(F_{1,4}=267, P<0.0001 ;\right.$ Fig. 7$)$. Across all five localities, papilla length was longer in pins $(0.047 \pm$ $0.001 \mathrm{~mm}, \quad \mathrm{CV}=0.26)$ than in thrums $(0.029 \pm$ $0.0004 \mathrm{~mm}, \mathrm{CV}=0.28$ ), which was a significant effect between morphs $\left(F_{1,4}=267, P<0.0001\right)$. A significant interaction between locality and morph $\left(F_{4,70}=6.07\right.$, $P<0.0001)$ was present, and individuals within locality varied significantly $\left(F_{70,450}=3.40, P<0.0001\right)$.

\section{Discussion}

All populations of Hedyotis caerulea surveyed here were isoplethic even though small populations of distylous species often show skewed morph ratios as a result of genetic drift (e.g., Eckert and Barrett 1992; Husband and Barrett 1992; Endels et al. 2002; Kéry et al. 2003). Surveys of $H$. caerulea localities previously done in North Carolina expressed greater variation in morph frequencies per locality, and pins outnumbered thrums by a ratio of 1.5:1 in most of the localities surveyed (Ornduff 1980). Wyatt and Hellwig (1979) also found that pins frequently 
Table 2 Correlation matrix where values $(r)$ for pins $(N=400)$ are on the top portion of the matrix, and those for thrums $(N=380)$ are on the base: width of corolla tube top (CT), width of corolla tube base
(CB), height of stigma (SH), distance between stigma and anther (DSA), stigma length (SL), and height of anther (AH). All measurements were taken in millimeters

\begin{tabular}{|c|c|c|c|c|c|c|}
\hline & CT & $\mathrm{CB}$ & SH & DSA & SL & $\mathrm{AH}$ \\
\hline \multirow[t]{2}{*}{ CT } & & 0.38 & 0.24 & 0.19 & 0.23 & 0.08 \\
\hline & & $<0.0001$ & $<0.0001$ & 0.0001 & $<0.0001$ & 0.13 \\
\hline \multirow[t]{2}{*}{ CB } & 0.41 & & 0.14 & 0.18 & 0.13 & 0.06 \\
\hline & $<0.0001$ & & 0.0056 & 0.0003 & 0.011 & 0.21 \\
\hline \multirow[t]{2}{*}{ SH } & 0.19 & 0.17 & & 0.89 & 0.51 & 0.18 \\
\hline & 0.0002 & 0.0007 & & $<0.0001$ & 0.0001 & 0.0002 \\
\hline \multirow[t]{2}{*}{ DSA } & 0.093 & -0.04 & -0.27 & & 0.53 & 0.09 \\
\hline & 0.070 & 0.42 & $<0.0001$ & & $<0.0001$ & 0.063 \\
\hline \multirow[t]{2}{*}{ SL } & 0.084 & 0.07 & 0.50 & -0.17 & & 0.03 \\
\hline & 0.10 & 0.17 & $<.0001$ & 0.0009 & & 0.61 \\
\hline \multirow[t]{2}{*}{$\mathrm{AH}$} & 0.23 & 0.10 & 0.53 & 0.67 & 0.24 & \\
\hline & $<0.0001$ & 0.056 & $<0.0001$ & $<0.0001$ & $<0.0001$ & \\
\hline
\end{tabular}

$P$ values are given below each correlation coefficient

outnumbered thrums in small populations, but when they pooled all results, morph frequency was deemed isoplethic. Both Wyatt and Hellwig (1979) and Ornduff (1980) suggested that over the course of a flowering season morph frequencies may fluctuate in some predictable pattern, but the present study identified no temporal trend. A 1:1 balance of morph frequencies in a population is achieved when the species' mating system promotes intermorph pollen transfer (disassortative mating) with nearly $100 \%$ outcrossing (Barrett 1992; Van Rossum and Triest 2006) and when the two morphs are of equal fitness. Pollination experiments in $H$. caerulea by Ornduff (1977) demonstrated that a thrum $\times$ thrum cross produces only about $5 \%$ of the seeds obtained in an intermorph cross, and pin $\times$ pin crosses produced no seeds even though pin pollen grains may outnumber thrum pollen grains on pin stigmas collected in nature (Ornduff 1980). Attempts to repeat these experiments in the field were unsuccessful largely because of the delicate nature of these flowers (Sampson 2010), but in sum, the results suggest that morphs are similar in reproductive success through optimal availability of compatible pollen, as argued for other species (Matsumura and Washitani 2000; Kéry et al. 2003; Shibayama and Kadono 2003).

Variation in the external floral morphology likewise infers a stable reproductive strategy in $H$. caerulea. The species clearly maintains two distinct morphs with little, if any, overlap in sizes of male and female reproductive characters. The two morphs differ in regard to the heights of their stigmas and anthers, and therefore meet the first of three criteria needed to qualify their mating system as distylous (Barrett and Shore 2008). Predicted to follow is reciprocal herkogamy (i.e., having exact reciprocity of placement between stigmas and anthers between floral morphs) because precise reciprocity would suggest that functionally equivalent amounts of pollen are carried from one morph to the other (Richards and Koptur 1993; Faivre and McDade 2001).

That a distylous mating system actually requires precise symmetry, however, is doubtful. Ganders (1979) found that differences of as little as $2 \mathrm{~mm}$ in stigma and anther height in pin flowers of Lithospermum californicum (Boraginaceae) significantly affected the degree of legitimate pollination, but not the stability of distyly. Deviation in symmetry also occurred in $H$. caerulea where flower size of thrums exceeded that of pins by over $20 \%$, as measured by dry weight, and locality variation was present in most of the measured morphological traits. A larger mass probably relates to the wider corolla tube of thrums, and one possibility is that these differences might relate to pollinators and/or pollen transfer in nature. Pins produce smaller pollen than do thrums, but make more of them. As a relationship between pollen size and pollen production occurs in other distylous species (Ganders 1979; Richards 1986; Dulberger 1992; Chen and Zhang 2010), and pollinators may transport these pollen morphs differently (Cruden 2009), connecting pollen size and pollinatorbearing area to pollen placement remains an important question for understanding reproductive investment in distylous systems that has yet to be studied in $\mathrm{H}$. caerulea.

In addition to flower size differences, two of the three measures used to assess reciprocity suggest some asymmetry in the herkogamy of $H$. caerulea. First, Faivre and McDade (2001) propose that the absolute value of the difference between anther and stigma heights should be identical between floral morphs; that condition was met. 

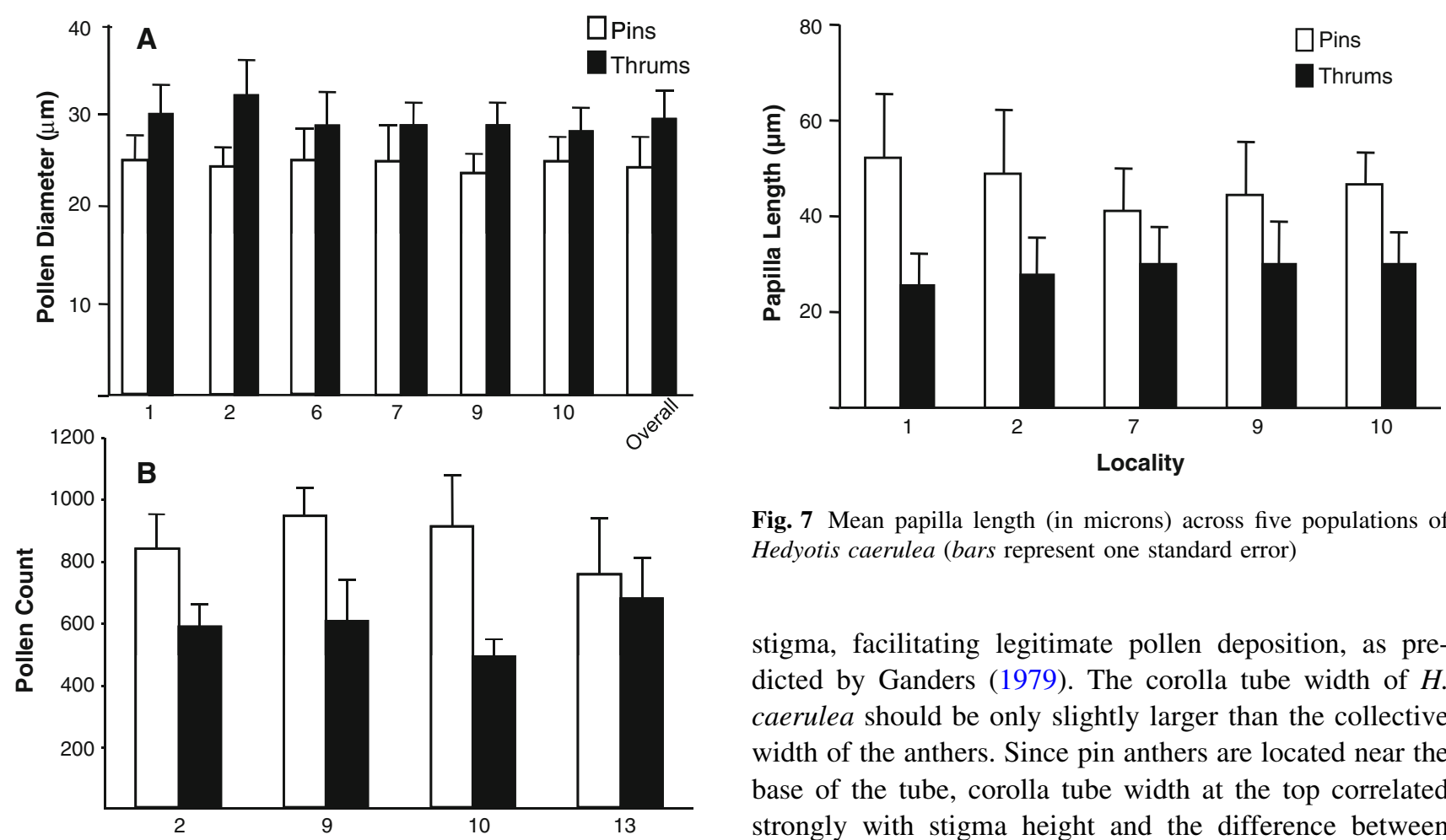

Fig. 7 Mean papilla length (in microns) across five populations of Hedyotis caerulea (bars represent one standard error)

stigma, facilitating legitimate pollen deposition, as predicted by Ganders (1979). The corolla tube width of $H$. caerulea should be only slightly larger than the collective width of the anthers. Since pin anthers are located near the base of the tube, corolla tube width at the top correlated strongly with stigma height and the difference between stigma height and anther height. Conversely in thrums,

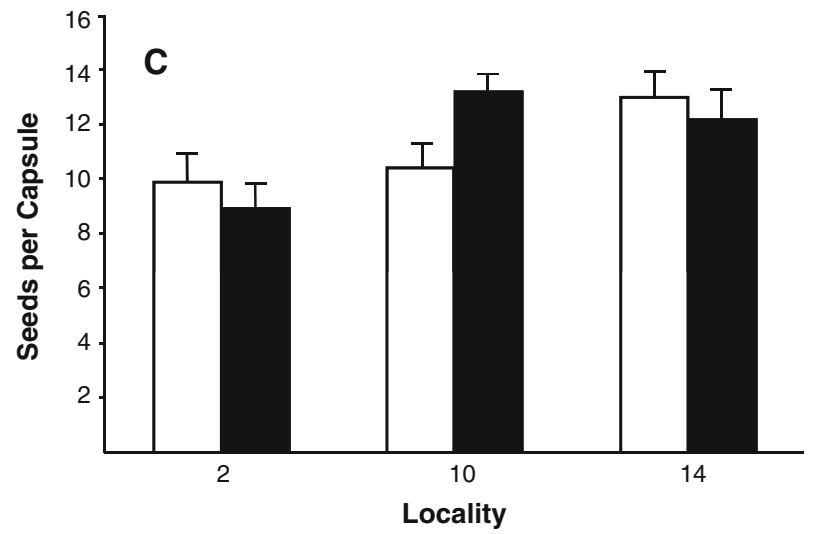

Fig. 6 The measurement of several reproductive characters in Hedyotis caerulea (bars represent one standard error): a mean pollen diameter (in microns) across six populations, b pollen counts per single anther sac from four populations, and $\mathbf{c}$ seed counts per capsule from three populations

However, the more direct second comparison of the mean heights of the two long organs and the two short organs suggests differences in growth between the two morphs. Third, the relative reciprocity index $(\mathrm{R})$ varied from that found in other Rubiaceae (Richards and Koptur 1993; Pailler and Thompson 1997) because stigma placements of the pins in $H$. caerulea are much shorter than those for the anthers of thrums.

Despite these differences, most ancillary features of $H$. caerulea are consistent with distyly. For one, the sex organs are enclosed within a tube beneath the petals, and pollen is held inside this tube either above or below the corolla tube width at the top (where anthers are positioned) correlated strongly with anther height.

Morphology related to pollen receptivity likewise varied between morphs. While stigma lengths are similar in the two morphs, the stigma is covered by stigmatic papillae, which increase the surface area and provide grooves in which pollen grains fit. These characters differed in the two morphs; thrum flowers have short papillae and pin flowers have long papillae. Therefore, symmetry appears with respect to size, which may facilitate legitimate pollen capture; the smaller pin pollen interacts with the smaller thrum papillae, and the larger thrum pollen interacts with the larger pin papillae.

The functional significance of the pollen-papillae relationship is unclear, however. Darwin (1877) suggested that thrum pollen is larger because the pathway down the longer pin style would require a greater store of nutrients. In the Primula model of the heterostyly supergene, the characteristics of the female reproduction organ (gynoecium), including stigma height and length, would be located at one genetic locus, while pollen size and development of the male reproductive organ (androecium) lie on a separate locus (Richards 1997). In H. caerulea, stigma length correlated strongly with stigma height, and pin flowers produced smaller pollen grains than thrum flowers. These results suggest that style-length variation and pollen size variation are controlled by different genes, which helps explain the extensive variation among diverse distylous groups for the relationship between pollen grain size and style length (Cruden 2009). 
Among those traits predicted to affect fitness, corolla tube shape, stigma morphology, and pollen size, variation across the localities sampled was almost always significant and generally considerable, as is common with fitness components (Price and Schluter 1991; Houle 1998). For example, Conner et al. (2003) quantified levels of phenotypic variation in many of these traits within radishes, noting high variance levels both in greenhouse experiments and in field samples, although high variance levels from the field collections largely precluded separation of genetic and environmental influences to the traits. The variation reported here in $H$. caerulea for flowers collected at different localities was expressed either as differences among the means for pins and thrums sampled at each locality or as interaction effects between morph and locality. Population variation is commonly considered to reflect opportunities to adapt over time (Hansen et al. 2003). Although all traits were sampled from a number of localities, no consistent spatial patterns occurred across our analyses; i.e., samples from neighboring localities did not tend to be any more similar than those from more distant sites. Neither were any obvious habitat differences, like sun exposure, found to relate to patterns of variation (Sampson 2010). Therefore, why does so much variation exist? Fisher (1930) suggested that fitness-relevant traits under selection should exhaust additive genetic variation. Variation present in these field populations may combine dominance, pleiotropic and epistatic effects to low levels of additive variation across the various structures measured (Kelly 2005; Kaczorowski et al. 2008). The distylous mating systems is maintained because selection favors two stable flower forms, even though the genetic background causes differences in anther and stigma heights in H. caerulea to be not precisely reciprocal. Variation in ancillary traits further supports that the dimorphism has not yet reached fixation, but the mating system is likely stable. Individual floral traits can change rapidly in response to selection (Lehtila and Holmen Brann 2007), as may ancillary traits such as pollen size (Lamborn et al. 2005), but how a suite of floral characters may shift in time is unknown. Clarifying the genetic relationships in distylous systems awaits future experimentation, probably in a more tractable species than H. caerulea.

Acknowledgments Suggestions from two anonymous reviewers greatly improved the manuscript. We thank Mike Walton, Harry van Keulen, and Paul Doerder for their assistance on the dissertation committee of DAS and the late Tarun Mal for introducing us to bluets. Dan Petit and Chuck Thomas granted permission and provided information on localities within the Cleveland Metroparks. Kyle Koiloni was a tremendous help in the field.

\section{References}

Baker HG (1956) Pollen dimorphism in the Rubiaceae. Evolution 10:23-31
Barrett SCH (1992) Heterostylous genetic polymorphisms: model systems for evolutionary analysis. In: Barrett SCH (ed) Evolution and function of heterostyly. Springer-Verlag, Berlin, pp 1-29

Barrett SCH, Eckert CG (1990) Variation and evolution in mating systems in seed plants. In: Kawano S (ed) Biological approaches and evolutionary trends in plants. Academic Press, London, pp 229-254

Barrett SCH, Shore JS (2008) New insights on heterostyly: comparative biology, ecology and genetics. In: Franklin-Tong VE (ed) Self incompatibility in flowering plants. Springer-Verlag, Berlin, pp 3-32

Chen ML, Zhang XP (2010) Distyly in Polygonum jucundum Meisn. (Polygonaceae). Plant Syst Evol 288:139-148

Cohen JI (2010) "A case to which no parallel exists": the influence of Darwin's Different Forms of Flowers. Am J Bot 97:701-716

Conner JK, Franks R, Stewart C (2003) Expression of additive genetic variances and covariances for wild radish floral traits: comparison between field and greenhouse environments. Evolution 57:487-495

Cruden RW (2009) Pollen grain size, stigma depth, and style length: the relationships revisited. Plant Syst Evol 278:223-238

Darwin C (1877) The different forms of flowers on plants of the same species. Murray, London

Dulberger R (1970) Tristyly in Lythrum junceum. New Phytol 69:751-759

Dulberger R (1974) Structural dimorphism of stigmatic papillae in distylous Linum species. Am J Bot 61:238-243

Dulberger R (1975) Intermorph structural differences between stigmatic papillae and pollen grains in relation to incompatibility in Plumbaginaceae. Proc Roy Soc London Series B 188:257-274

Dulberger R (1992) Floral polymorphisms and their functional significance in the heterostylous syndrome. In: Barrett $\mathrm{SCH}$ (ed) Evolution and function of heterostyly. Springer-Verlag, Berlin, pp 41-84

Eckert CG, Barrett SCH (1992) Stochastic loss of style morphs from populations of tristylous Lythrum salicaria and Decodon verticillatus (Lythraceae). Evolution 46:1014-1029

Endels P, Jacquemyn H, Brys R, Hermy M (2002) Changes in pinthrum ratios in populations of the heterostyle Primula vulgaris Huds: does imbalance affect population persistence? Flora 197:326-331

Faivre AE, McDade LA (2001) Population-level variation in the expression of heterostyly in three species of Rubiaceae: does reciprocal placement of anthers and stigmas characterize heterostyly? Am J Bot 88:841-853

Fisher RA (1930) The genetical theory of natural selection. Clarendon Press, Oxford

Ganders FR (1979) The biology of heterostyly. NZ J Bot 17:607-635

Grimaldi D (1988) Bee flies and bluets: Bombylius (Diptera: Bombyliidae) flower-constant on the distylous species, Hedyotis caerulea (Rubiaceae), and the manner of foraging. J Nat Hist 22:1-10

Hansen TF, Pelabon C, Armbruster WS, Carlson ML (2003) Evolvability and genetic constraint in Dalechampia blossoms: components of variance and measures of evolvability. J Evol Biol 16:754-766

Heuch I (1979) Equilibrium populations of heterostylous plants. Theor Pop Biol 15:43-57

Houle D (1998) How should we explain variation in the genetic variance of traits? Genetica 102:241-253

Husband BC, Barrett SCH (1992) Genetic drift and the maintenance of the style length polymorphism in tristylous populations of Eichhornia paniculata (Pontederiaceae). Heredity 69:440-449

Kaczorowski RL, Juenger TE, Holtsford TP (2008) Heritability and correlation structure of nectar and floral morphology traits in Nicotiana alata. Evolution 62:1738-1750 
Kelly JK (2005) Epistasis in monkeyflowers. Genetics 171:1917-1931

Kéry M, Matthies D, Schmid B (2003) Demographic stochasticity in population fragments of the declining distylous perennial Primula veris (Primulaceae). Basic Appl Ecol 4:197-206

Lamborn E, Cresswell JE, Macnair MR (2005) The potential for adaptive evolution of pollen grain size in Mimulus guttatus. New Phytol 167:289-296

Lehtila K, Holmen Brann K (2007) Correlated effects of selection for flower size in Raphanus raphanistrum. Can J Bot 85:160-167

Lloyd D, Webb C (1992a) The evolution of heterostyly. In: Barrett $\mathrm{SCH}$ (ed) Evolution and function of heterostyly. SpringerVerlag, Berlin, pp 157-178

Lloyd D, Webb C (1992b) The selection of heterostyly. In: Barrett $\mathrm{SCH}$ (ed) Evolution and function of heterostyly. SpringerVerlag, Berlin, pp 179-207

Mather K, De Winton D (1941) Adaptation and counter-adaptation of the breeding system in Primula. Ann Bot 5:297-311

Matsumura C, Washitani I (2000) Effects of population size and pollinator limitation on seed-set of Primula sieboldii populations in a fragmented landscape. Ecol Res 15:307-322

Oleson JM (1979) Floral morphology and pollen flow in the heterostylous species Pulmonaria obscura Dumort (Boraginaceae). New Phytol 82:757-767

Ornduff R (1970) Incompatibility and the pollen economy of Jepsonia parryi. Am J Bot 57:1036-1041

Ornduff R (1976) The reproductive system of Amsinckia grandiflora, a distylous species. Syst Bot 1:57-66

Ornduff R (1977) An unusual homostyle in Hedyotis caerulea (Rubiaceae). Plant Syst Evol 127:293-297

Ornduff R (1978) Features of pollen flow in dimorphic species of Lythrum section Euhyssopifolia. Am J Bot 65:1077-1083

Ornduff R (1980) Heterostyly, population composition, and pollen flow in Hedyotis caerulea. Am J Bot 67:95-103

Pailler T, Thompson JD (1997) Distyly and variation in heteromorphic incompatibility in Gaertnera vaginata (Rubiaceae) endemic to La Reunion Island. Am J Bot 84:315-327
Pandey KK, Troughton JH (1974) Scanning electron microscopic observation of pollen grains and stigma in the self-incompatible heteromorphic species Primula malacoides Franch. and Forsythia intermedia Zab., and genetics of sporopollenin deposition. Euphytica 23:337-344

Price T, Schluter D (1991) On the low heritability of life-history traits. Evolution 45:853-861

Richards AJ (1986) Plant breeding systems. G. Allen \& Unwin, London

Richards AJ (1997) Plant breeding systems, 2nd edn. Chapman \& Hall, London

Richards JH, Koptur S (1993) Floral variation and distyly in Guetarda scabra (Rubiaceae). Am J Bot 80:31-40

Sampson DA (2010) An assessment of the evolutionary stability of distyly in Hedyotis caerulea (Rubiaceae). Dissertation, Cleveland State University

Shibayama Y, Kadono Y (2003) Floral morph composition and pollen limitation in the seed set of Nymphoides indica populations. Ecol Res 18:725-737

Sutherland S, Delph LF (1984) On the importance of male fitness in plants: patterns of fruit set. Ecology 65:1093-1104

Van Rossum F, Triest L (2006) Within-population genetic variation in the distylous Primula veris: Does floral morph anisoplethy matter in fragmented habitats? Perspect Plant Ecol Evol Syst 7:263-273

Vuilleumier BS (1967) The origin and evolutionary development of heterostyly in the angiosperms. Evolution 21:210-226

Webb CJ, Lloyd DG (1986) The avoidance of interference between the presentation of pollen and stigmas in angiosperms II. Herkogamy. NZ J Bot 24:163-178

Weller SG (2009) The different forms of flowers-what we have learned since Darwin? Bot J Linn Soc 160:249-261

Wyatt R, Hellwig R (1979) Factors determining fruit set in heterostylous bluets, Houstonia caerulea (Rubiaceae). Syst Bot 4:103-114 